\title{
Pushed out of the education system: using a natural experiment to evaluate consequences for boys
}

\author{
Kira Solveig Larsen ${ }^{1}$ (D) - Lars Højsgaard Andersen ${ }^{2} \cdot$ Britt Østergaard Larsen ${ }^{1}$
}

Accepted: 2 September 2020/Published online: 6 October 2020

(C) The Author(s) 2020

\section{Abstract}

Objectives To examine the short-term effects of admission requirements for upper secondary vocational education and training (VET) on enrollment and criminal offending among academically low-achieving boys.

Methods We apply multi-group difference-in-differences models to full population data and analyze an educational policy reform in Denmark $(N=60,759)$.

Results The reform caused a 16 percentage points lower enrollment in VET among academically low-achieving boys, and their risk of being charged with a crime increased by up to two percentage points 9 months after the end of compulsory school. However, after 12 months, the effect on criminal charges disappeared.

Conclusion In the education-crime nexus, educational enrollment in upper secondary education is an understudied margin, which has important implications for both scholars and policy-makers. Limitations include the short follow-up period and that the analyses examine effects for boys only.

Keywords Difference-in-differences model · Education · Natural experiment · Registry data $\cdot$ Policy reform

\section{Introduction}

Given that educational attainment influences health, employment, and income, it plays a significant role in determining individuals' long-term outcomes (e.g., Card 1999; Oreopoulos and Salvanes 2011). Not surprisingly, there is a large criminological literature evaluating the effects of, for example, dropout from education on subsequent

Kira Solveig Larsen

kila@vive.dk

1 Danish Center for Social Science Research, 1052 Copenhagen, Denmark

2 ROCKWOOL Foundation Research Unit, 1472 Copenhagen, Denmark 
crime. In general, these dropout studies support evidence of the education-crime link (e.g., Bäckman 2017; Elliott and Voss 1974; Farrington et al. 1986; Thornberry et al. 1985), although a few studies find more ambiguous results (Bachman et al. 1978; Jarjoura 1993) or no long-term effect of dropout on crime (Sweeten et al. 2009). Missing from these dropout studies, however, is the question of the crime-reducing benefits of enrolling in education. Thus, as well as other long-term outcomes of education, it is important to examine the effects of educational enrollment on criminal behavior in order to achieve a richer scholarly understanding of the potential benefits of education and of how to prevent criminal careers.

To analyze the education-crime relationship, studies have used a range of methodological approaches, such as propensity score matching (e.g., Bäckman 2017) and other advanced quantitative methods (e.g., Bjerk 2012; Sweeten et al. 2009). The present study contributes to a recent line of research using natural experiments to examine the effects of education on crime along two lines. First, most of these studies provide knowledge on the effects of the length of education, school starting age, and school attendance on criminal behavior (e.g., Bell et al. 2016; Brugård and Falch 2013; Landersø et al. 2017; Luallen 2006). Therefore, almost all of these studies are based on comparisons within the population of students who are (or have been) enrolled in education. However, there can be substantial (unobserved) differences between the population of adolescents in and outside of the education system, as pointed out by, for example, Sweeten et al. (2009) and Kirk and Sampson (2013), who document significant differences between dropouts and students. Hence, we argue that educational enrollment is a central margin and therefore needs to be a central focus in research on the effects of education on crime.

Second, the vast majority of studies applying experimental designs focus on the effects of compulsory schooling (e.g., Beatton et al. 2018; Hjalmarsson et al. 2015; Lochner and Moretti 2004; Machin et al. 2011). More recently, a new literature exploiting natural experiments to estimate the effects of upper secondary education on crime has emerged, and the results obtained support that upper secondary education reduces crime among men (e.g., Åslund et al. 2018). These studies still do not focus on the enrollment margin (except for Huttunen et al. 2019, to which we will turn shortly), although enrollment in upper secondary education occurs at a pivotal time in life (typically at ages 15-18 in Denmark, the context of our study). This is the years in which criminal activity peaks (Moffitt 1993; Piquero et al. 2003) and when education may have a great potential to prevent criminal behavior in the long term (Bell et al. 2018). Given the research findings on the links between education and crime, and the timing of enrollment in upper secondary education relative to the shape of the agecrime curve, the absence of studies examining the effects of enrollment in upper secondary education on crime is striking. One exemption is Huttunen et al. (2019), who analyze the effects of enrollment by exploiting admission cutoffs for upper secondary education in Finland. They find that successful applicants are less likely to commit crime during the first 5 years after admission to secondary education than are applicants with a grade point average (GPA) just below the admission cutoff.

In this study, we contribute to the existing literature by examining the effects of enrollment in upper secondary education on the criminal offending of low-achieving boys. We do this by exploiting a 2015 Danish educational policy reform that introduced grade-specific admission requirements for vocational education and training (VET). 
Before the reform, all Danish students could enroll in VET if their ninth-grade teacher evaluated them as sufficiently motivated and skilled. In contrast, after the reform, in addition to a positive teacher evaluation, enrollment in VET required students to meet certain GPA levels in math and Danish. Thus, the reform targets only those adolescents who scored low in their compulsory schooling final exams (hereinafter referred to as "low-achieving adolescents"). While some low-achieving adolescents may have low academic abilities, others may be weighed down by contextual factors, and some may even suffer from both.

As enrollment rates can be low and levels of criminality high among low-achieving adolescents (e.g., Maguin and Loeber 1996), the question of whether educational enrollment affects low-achieving boys' risk of engaging in criminal behavior is particularly crucial. In Denmark, upper secondary education consists of two tracks, namely, a VET track and an academic track (i.e., academic high school), with graduation from one or the other being a prerequisite for entering skilled employment later in life. The transition to VET may be especially important for low-achieving boys, both as the first step towards entering skilled employment and because VET is the preferred educational track in this group. ${ }^{1}$ Although the reform also affects low-achieving girls, this study does not include girls because the rate of criminal charges among girls in Denmark is so low that we would not be able to make separate statistical analyses for them.

We expect that the Danish policy reform introducing admission requirements will have decreased the likelihood of low-achieving boys enrolling in VET, thereby preventing them from obtaining an upper secondary education. As we explain in detail in the section on "Context and policy reform," these boys are essentially pushed out of the upper secondary education system. Drawing on criminological theory, we argue that if the reform prevents low-achieving boys from enrolling in upper secondary education, their criminal behavior may increase. To explain how not enrolling in upper secondary education can affect criminal behavior, we include the following three theoretical perspectives.

First, finishing compulsory school and entering upper secondary education is an important transition in adolescence. According to social bonds theory, the absence of bonds to certain norms or institutions, such as educational institutions, can decrease moral attachment to other people and thereby increase criminal behavior (Hirschi 1969). Building on Hirschi's theory, Laub and Sampson's (1993) life course theory focuses on changes in social bonds over the life course. They find that age itself does not underlie the likelihood of criminal behavior among adolescents: instead, they argue that changes in social bonds occurring at the age when the crime curve peaks underlie the increasing risk of adolescent criminal behavior (Laub and Sampson 1993). Hence, boys who go straight from compulsory schooling to idleness will lack the opportunity to create stable social bonds in the education system at a critical age. Thus, if the Danish reform decreases low-achieving boys' transition to upper secondary education, this can prevent them from continuing in the education system and hence affect their social bonds and attachments. Therefore, we expect that the reform has inadvertently increased the criminal behavior of this group of boys.

\footnotetext{
${ }^{1}$ In 2014, the last year before the reform, $80 \%$ of adolescents in the lowest percentile of grade point averages in Danish and math enrolled in the vocational track, $10 \%$ enrolled in the academic track, and $10 \%$ left the education system (DEA 2016).
} 
Second, the new admission requirement introduced by the reform may prevent some boys who expected to enroll in VET from entering upper secondary education. Because the boys do not know whether they will fulfill the admission requirements for VET when they apply for upper secondary education, it is credible that some low-achieving boys did have realistic expectations of enrolling in VET, and not mere unrealistic aspirations. Thus, the failure to enroll in VET may lead to a gap between their expected goals and their achieved goals. According to general strain theory, when others prevent someone from achieving their expected positively valued goal, the resulting strain may cause feelings of anger, disappointment, and frustration, which can result in criminal behavior-especially among adolescents and if the expected goal is realistic to achieve (Agnew 1992; Agnew et al. 2002). Some empirical studies investigating strain as a potential explanation of the education-crime link find support of strain theories (e.g., Bäckman 2017; Elliott and Voss 1974; Jarjoura 1993), while other studies find that other explanations are more plausible (e.g., Thornberry et al. 1985). We expect that if the reform prevents low-achieving boys with vocational expectations from enrolling in VET, these boys will suffer emotional strain, which in turn may lead to criminal behavior.

Third, students spend their days in a classroom under teacher supervision, and thereby education incapacitates students, potentially preventing them from committing crime. The lack of such supervision for boys unable to enroll in VET can also play a role, if the reform leads to an increase in crime rates. According to routine activity theory, a criminal act may be less likely to occur in the presence of a capable guardian, for example, a teacher (Cohen and Felson 1979). Empirical research examining the effects of teachers-in-service days and teacher strikes (Jacob and Lefgren 2003; Luallen 2006) and the effects of extending VET programs (Åslund et al. 2018) find support for incapacitation effects. Therefore, we can expect that if the reform prevents lowachieving boys from enrolling in VET and increases their idleness, it can increase the likelihood of criminal behavior.

To summarize, we argue that the age timing of the reform - which can prevent lowachieving boys from continuing in the education system - is crucial. Thus, the 2015 reform can prevent transition to upper secondary education for one of the groups that is most at risk of getting caught up in the criminal justice system: Young and academically low-achieving boys. To measure the consequences hereof, we use full population data from Denmark and multi-group difference-in-differences models $(N=60,759)$. Our results lead to the overall conclusion that the reform indeed decreased VET enrollment and in the short-term (although to a lesser degree) increased the risk of criminal charges among low-achieving boys. We therefore argue that educational enrollment in upper secondary education is a key margin of the education-crime nexus that deserves more attention from both research and public policy. Limitations of our study include the short follow-up period and that analyses include boys only. Yet despite these limitations, we believe our study provides new knowledge on an especially important margin of the education-crime link.

\section{Context and policy reform}

The Danish educational system has a compulsory 10-year program (grades 0 to 9) with an optional 11th year, called 10th grade (see Fig. 1 for an illustration of the Danish 


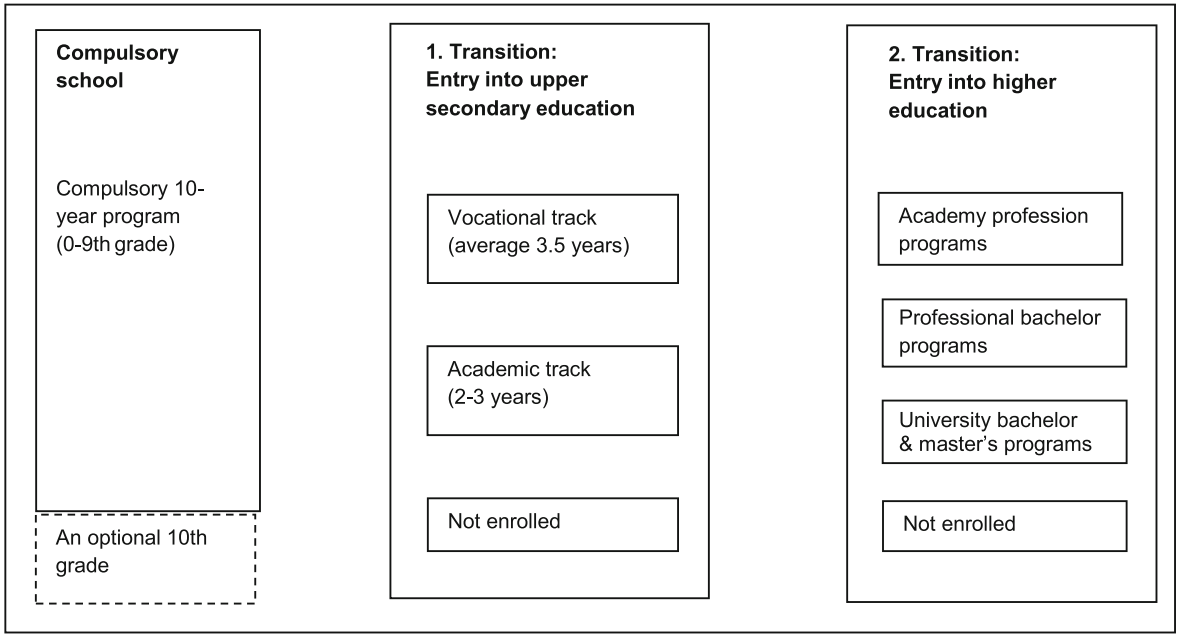

Fig. 1 Illustration of the Danish Education System

education system, including compulsory school, upper secondary education, and higher education). In a Danish cohort, every second student enrolls in the optional 10th grade in compulsory school. Low-achieving students can use 10th grade to prepare for enrollment in upper secondary education, but 10th grade is also commonly used as a sabbatical year among middle- and high-achieving students, hence the high percentage. After completing compulsory school, students can enroll in upper secondary education, which consists of two tracks: the academic track and vocational education and training (VET). ${ }^{2}$ The academic track has a duration of 2 to 3 years and qualifies students for higher education. The vocational track (under analysis here) includes a school-based basic program (typically 20-40 weeks) and a main program, which is a mix of incompany training and school periods. A VET program typically takes $3 \frac{1}{2}$ years to complete and qualifies students to enter skilled employment. ${ }^{3}$ The Danish VET programs cover about 110 different specializations, e.g., carpenters, hairdressers, healthcare assistants, and retail workers. Tuition is tax-covered at all levels of the Danish educational system and students above the age of 18 receive a monthly financial grant. $^{4}$

\footnotetext{
${ }^{2}$ Educational enrollment after ninth grade for 15-18-year-old boys who had just finished ninth grade in 2014: $34 \%$ of the boys entered the academic track, $11 \%$ enrolled in the vocational track, $49 \%$ continued in 10th grade, and 6\% did not continue in the education system (see Table 4 in the Appendix). For the students who finish the ninth grade and do not enroll in 10th grade nor upper secondary education, there are three overall alternatives: (1) they can undertake unskilled employment with low wages, low job security, and limited career prospects; (2) they can be unemployed or job seeking, which entails low social benefits for people under age 30 and comes with several activity requirements; or (3) they can be self-supporting, which basically implies being financially dependent on their parents.

${ }^{3}$ The vocational track qualifies students for some higher education programs as well. However, typically Danish VET students enter skilled employment directly after graduating VET.

${ }^{4}$ For students aged 18 to 19 , the public financial grant is in the range of USD 150-400 per month. Students in VET programs who have a contract with a private company for an apprenticeship will receive a trainee salary from the company. The trainee salary typically starts at USD 1400-1900 per month.
} 


\section{The policy reform}

In Denmark, the procedure for transition from compulsory school to upper secondary education is as follows. Students who are enrolled in ninth grade (or 10th grade) can apply for an upper secondary education in the beginning of March, the year in which they finish ninth grade. Final exams take place in June, and shortly after the students receive their final grades (on a scale from -03 to 12 , where the grade 02 corresponds to "just passed"). At the end of June, students receive notification of whether they have been admitted to the programs they applied for in March.

However, in August 2015, the Danish Government introduced new admission rules to upper secondary education. The procedure mentioned above was the same before and after the policy reform, only the admission requirements changed. Before 2015, ninth-grade teachers subjectively assessed whether a student was qualified for enrollment in upper secondary education, and there were no formal grade-specific requirements to enroll in either the academic or the vocational track. In contrast, after August 2015, students who apply for VET programs are required to have an average of minimum 02 (corresponding to "just passed") in Danish and an average of minimum 02 in math in their final exams in ninth or 10th grade in order to enroll.

The new admission requirements for the vocational track were part of a comprehensive policy reform aimed at making the VET programs more attractive to students (The Danish Government 2014). ${ }^{5}$ The political parties behind the reform formalized an agreement on its execution in February 2014, and on May 8, 2014, the Minister of Children and Education proposed the policy reform (including the admission requirement) to the Danish Parliament, which approved the bill on June 11, 2014. The overall political ambition with the reform was to increase completion rates of the Danish VET programs, as these programs had had high dropout rates for many years, especially among low-achieving students (the Danish Ministry of Children and Education 2018). Specifically, there were three political arguments for introducing the admission requirement: first, to prevent academically low-achieving adolescents from academic failure because they commenced a VET program that they did not possess sufficient academic skills to complete; second, to make the vocational track more attractive to higher-ability students; and third, to ensure a more homogenous group of students (in relation to academic skills) in order to improve the teaching environment.

Students who do not fulfill the admission requirement when leaving compulsory school can still enroll in VET if they either have a contract with a private company for an apprenticeship or pass an admission test (corresponding to a ninth grade exam). Non-eligible students who applied for admission to a VET program receive an invitation to the admission test and receive the results from the test in July. Students who pass the test can then enroll in August together with the students who were eligible in the first place. Official statistics show that application numbers for VET were stable across 2015, the reform year (the Danish Evaluation Institute 2018), and that the admission test prevented a substantial number of adolescents who applied for VET directly after finishing compulsory school from enrolling in VET (the Danish Ministry of Children

\footnotetext{
5 The policy reform of the VET programs also entailed introducing more sport activities, elements supporting better school environments, and making structural changes to help students navigate between the many different VET programs.
} 
and Education 2015). Both statistics indicate that the reform prevented some lowachieving adolescents who expected to enroll in VET from entering VET programs.

As mentioned above, students take their final exams in June. Thus, when they apply for upper secondary education in March, they do not know whether or not they are eligible for VET. In the Danish education system, students receive end-of-year grades in eighth grade, and in most cases, these grades will be a good benchmark for the students' eligibility. Therefore, students in the higher end of the grade scale will generally know that they are eligible. Some youths, though, find themselves at the margin of the admission requirement and will thus not know whether they will achieve high enough grades to be eligible - especially because the admission requirement involves six different grades in math and Danish.

\section{Data and method}

\section{Data}

We use register data for the full population of ninth graders in Denmark from 2005 to 2016. Danish register data, available for research through Statistics Denmark, comprise administrative data from various agencies, such as the Ministry of Education and the National Police. Information on each resident in Denmark is recorded using a unique anonymized identification number, which enables researchers to link individual-level information across registers and time (Andersen 2018).

We merge data on GPA from the ninth grade final exams with data on education enrollment and data on criminal charges. All relevant registers are available from 2005 to ultimo 2016, except for that on criminal charges, which is available from 2005 through July 2016. In our main sample, we include boys aged 15 to 18 who completed ninth grade in 2014 or 2015 , which gives a total sample of 60,759 boys. This choice of sample is based on the following considerations: First, we include boys only, as criminal charges are measured during a 12-month window, and the crime rates of girls have too little variation to allow estimation of separate statistical models for girls (see the "Discussion" section for further considerations regarding limitations and future research). Other empirical studies which examine the effects of education on criminal behavior find substantially larger effects for males than females (Bennett 2018; Hjalmarsson et al. 2015; Machin et al. 2012), and they find that dropping out of high school has no effects for females (Bäckman 2017). Thus, we could risk underestimating the policy effect on crime for boys by estimating compound effects for boys and girls, which is another reason why we focus on boys only in this study. Second, we focus on boys who finished ninth grade in 2014 and 2015 to ensure a clear distinction between the control group (pre-reform) and treatment group (post-reform). Boys who finished ninth grade in 2015, the treatment group, did not have the opportunity to enroll in VET before the reform, which minimizes the risk of treatment migration. Boys who finished ninth grade in 2014, the control group, had the opportunity to enroll in VET right after finishing ninth grade in 2014 without being affected by the reform. The admission requirement also applies to 10th graders, but boys who finished 10th grade in 2015 could already have enrolled in a VET program in 2014 (before the reform) when they finished ninth grade. 
Third, we focus on boys age 15 to 18 at the end of ninth grade as this is the age at which students typically finish ninth grade in Denmark. Fourth, we exclude boys with missing information on grades from ninth grade final exams. ${ }^{6}$ Even though the ninth grade is compulsory in Denmark, about 6\% in each cohort do not complete their ninth grade final exams before turning 25 years of age (the Danish Economic Council of the Labour Movement 2013). ${ }^{7}$ Finally, we exclude boys who emigrated or died before September the year they finished ninth grade and who, therefore, are no longer "at risk" of entering upper secondary education or being charged with crimes.

\section{Variables}

A binary variable indicates whether a boy finished ninth grade in $2014(0=$ pre-reform control group) or 2015 ( 1 = post-reform treatment group).

As outcome variables, we focus on educational enrollment and criminal charges. Educational enrollment in VET measures each boy's education status 3, 6, 9, and 12 months after he finished ninth grade and is based on administrative information on enrollment date and type of education data from the Danish Ministry of Education. We have information on criminal charges from official charge records, which the Danish Central Crime Register of the Danish National Police reports to Statistics Denmark. This register includes case numbers, charge dates, offense dates, and offense types. The unique case and individual identifiers allow us to merge one charge record per case to each charged boy in that case. As we only have fully updated charge data available through to the end of July 2016, we measure criminal charges for offenses committed from the (potential) enrollment date to upper secondary education in August to July 31 st the following year (2015 for the pre-reform group, 2016 for the post-reform group). Importantly, we only include charge records for offenses that were committed in that period, which ensures that we may interpret charges as a behavioral outcome and ensures that we do not count offenses that preceded educational enrollment. Charge records contain official charges for offenses against the criminal code, which includes a range of different offense types (e.g., assault, robbery, burglary, theft, shoplifting, and vandalism), but because of the short measurement period, we pool all charges into one measure. We exclude violations of the Traffic Act, as official records of these offenses fluctuate greatly with varying police activity.

Finally, we include a range of background characteristics from other registers. From the demographic registers, we add age and ethnicity, and from the criminal justice registers, we add criminal history measured as whether the boy has any prior charges. For each boy, we include information on parents' employment status and educational background, as well as parental household income rank.

\footnotetext{
${ }^{6}$ The share of boys with missing grade information is stable across the different years: $7 \%$ in $2012,8 \%$ in $2013,8 \%$ in 2014 , and $7 \%$ in 2015 .

${ }^{7}$ The admission requirement also excludes those without grades from admission to VET, which implies that we could simply count this group as ineligible for VET after the reform. Here, we would expect boys without ninth grade final exams to have low educational enrollment and high criminal activity. However, analyses show that the group is heterogeneous, indicating that missing grades is not exclusively a proxy for not showing up for the final exams. Information regarding the composition of the group with missing grade information is available upon request to the corresponding author.
} 


\section{Method and analytic plan}

To analyze the consequences of the 2015 reform, we take three analytical steps. In the first step, we provide descriptive evidence regarding the impact of the reform. Here, we describe the development in enrollment rates to VET from 2005 to 2016 for ninth grade students divided into groups by GPA. We do this to show that the reform was implemented and that the admission requirements decreased enrollment rates among low-achieving boys who did not fulfill the new requirements introduced by the reform. Furthermore, we describe enrollment rates into different types of upper secondary education to show that the group of boys on which we focus in this study indeed failed to enroll in any upper secondary education after the reform. Hence, they did not simply migrate to other educational tracks, which is important if we wish to use the reform to study the relationship between educational enrollment and crime. We also describe the development in charge rates from 2005 to 2016 for different GPA groups. We do this to show that even though the period is characterized by the well-known decline in youth crime (for Denmark, see Andersen et al. 2016) the descriptive evidence suggests that the charge rates of low-achieving boys are affected by the reform.

The finding that VET enrollment decreases while the rate of criminal charges increases is not evidence of a causal link between the two, however. This becomes evident when we document that the reform also led to a noteworthy change in grading patterns at ninth grade exams. Grade point averages inflated from 2014 to 2015 in ways that we do not observe for previous years or for subjects (English and natural sciences) other than those affected by the reform (math and Danish). This issue challenges our implicit claim of comparability (also on unobserved factors) between boys before and after the reform, as it could imply compositional changes to the groups of boys with the lowest GPA (caused by unobserved selection across the GPA threshold that was introduced by the reform). We therefore compare average background characteristics of the pre- and post-reform groups across different GPA groups to determine whether these compositional changes occur.

In the second analytical step, we turn to a difference-in-differences (DD) framework. This type of model is one of the most preferred models for measuring program effects in contexts where general time trends need to be factored out for them not to bias results (Angrist and Pischke 2008). Because there is a general decline in youth crime in Denmark across our study period, our empirical setup is exactly the type that calls for DD estimation. The principle behind the DD approach is that it compares the change in average outcomes from before the reform (2014) to after the reform (2015) for boys who were affected by the reform (low-achieving boys) to the same change for boys who were not affected by the reform (boys who fulfill the policy requirements). We then assume that the change in average outcomes across the policy reform for boys who were not affected by the reform expresses what the trends in average outcomes would have been for the treatment group if they had not been treated (this is the parallel trends assumption, Angrist and Pischke 2008). For criminal charges, the basic DD model can be formalized as follows:

$$
\rho^{D D}=\Delta \overline{C H A R G E S}_{G P A<02}-\Delta \overline{C H A R G E S}_{G P A \geq 02}
$$


In our specific empirical setup, however, there is reason to suspect that unobserved selection across the grade point threshold of 02 may have occurred as a result of the reform (because of grade inflation as discussed previously and documented in our first analytical step). Thus, there is a risk of bias in the estimation of $\rho^{D D}$ in Eq. (1). To circumvent this risk, we exploit the finding that the grade inflation from 2014 to 2015 did not only occur in the lower tail of the grade point average distribution; even for higher grade point averages we observe inflation. We now assume that the unobserved selection which occurs across the 02 threshold is mirrored by similar unobserved selection across another threshold in the grade point average distribution, the 07 threshold. To reach this end, we split the sample into groups as defined by the grade point average and set up the following multi-group extension to the DD model:

$$
\begin{gathered}
\rho^{D D^{*}}=\left[\Delta \overline{C H A R G E S}_{G P A<02}-\Delta \overline{C H A R G E S}_{02 \leq G P A<04}\right] \\
-\left[\Delta \overline{C H A R G E S}_{04 \leq G P A<07}-\Delta \overline{C H A R G E S}_{G P A \geq 07}\right]
\end{gathered}
$$

The first bracket of Eq. (2) measures the reform effect and the effect of unobserved selection across the 02 threshold. The second bracket measures the effect of unobserved selection across the 07 threshold, yet these grade groups were not affected otherwise by the reform. Subtracting the two brackets then isolates the reform effect (to the degree of similarity in unobserved selection across the 02 and 07 thresholds). It is important to note that although the DD setup does not require us to control for background characteristics, we still do so in order to increase the precision of our estimates. This means that we, in practice, estimate $\rho^{D D *}$ using a standard OLS regression model with robust standard errors. ${ }^{8}$

In terms of interpretability, our parameter of interest $\rho^{D D *}$ measures the effect of the 2015 reform for all boys who do not fulfill the admission requirement. It is thus an intention-to-treat (ITT) estimate (Angrist and Pischke 2008). As was described in the section about the Danish context, boys who do not fulfill the admission requirement can still enroll in VET if they either pass an admission test or have a contract with a private company for an apprenticeship. Some of the low-achieving boys may thus enroll in VET despite the reform. Moreover, it is important to stress that the alternative to enrolling in VET is not necessarily idleness. The admission requirements only pertain to upper secondary vocational education, which implies that the group of boys who do not fulfill the GPA requirement could pursue other types of education, such as the optional 10th grade in compulsory school. Consequently, we view our estimates of the effect of the reform on criminal charges as lower bound.

In the third and final analytical step, we acknowledge that our multi-group DD model extension relies on an assumption that is not straightforwardly justified. We therefore run a series of robustness analyses to bolster our claim of measuring the effects of the reform. Similar to our main model, the robustness analyses include covariates (for age, ethnicity, socioeconomic background, and criminal history) and robust standard errors. The robustness analyses are as follows: (A) Instead of focusing on the group of boys with grades below the 02 threshold, we estimate models by

\footnotetext{
${ }^{8}$ As all variables in the model are binary, the linear regression estimates are identical to marginal effects in nonlinear models (Angrist and Pischke 2008).
} 
comparing different percentiles in the grade point average distribution. Since the admission requirement requires minimum 02 in both Danish grade point averages and math grade point averages, we define GPA as the lowest of either Danish grade point averages or math grade point averages. We then assume that boys in the lowest $1 \%$ of the distribution in 2014 are comparable with boys in the lowest $1 \%$ of the distribution in 2015. Using the DD setup from Eq. (1), we then subtract the general trend from 2014 to 2015 for boys in the remaining $99 \%$ of the distribution from the trend for the lowest percentile to obtain a more credible estimate of the reform on both the enrollment rates and charge rates. We repeat this exercise running separate models for boys who fall below each percentile compared with the boys in the remaining part of the distribution. If this approach leads to estimates that differ substantially between boys in the GPA percentiles that the admission requirement affected and boys in the other percentiles, we interpret this as supporting our main result.

(B) We run a set of placebo tests to see if there are signs of any reform effects during years in which there was no reform. Here, we estimate multi-group DD models for each year from 2005 to 2014 (and for VET enrollment in 2016; as mentioned earlier we do not have charge data for this year). Traces of reform "effects" during these other years would indicate that our empirical setup could be driving the estimates and not the reform per se. (C) Instead of relying on the 07 threshold for mirroring potential unobserved selection across the 02 threshold, we re-estimate Eq. (2) using other thresholds for comparison. If the reform estimates are stable across these different definitions of the comparison groups, we may rest assured that the results are not driven exclusively by our choice of threshold in the multi-group DD models.

\section{Results}

\section{Descriptive evidence}

Figure 2 shows the proportion of boys aged 15 to 18 who enroll in a VET program from 2005 to 2016 using four follow-up periods (3, 6, 9, and 12 months after finishing ninth grade) and for four different GPA groups from ninth grade final exams: below 02, between 02 and 04, between 04 and 07, and above 07. The group labelled "GPA < 02" includes boys with an average below 02 in Danish or math. The group " $02<=$ GPA $<$ 04" includes boys with a GPA between 02 and 04 in Danish and math, the group "04< $=$ GPA $<07$ " includes boys with a GPA between 4 and 7, and the group "GPA $>=7$ " includes boys with a GPA of at least 7. From 2012 to 2014, about $20 \%$ of the boys who had an average below 02 in Danish or math in their final exams (low-achieving boys) enrolled in a VET program directly after ninth grade. In 2015, this number dropped to $8 \%$ when the admission requirement was introduced, which corresponds to a $62 \%$ decrease. One possible effect of introducing admission requirements is that the reform merely prevented enrollment in VET among boys who would have dropped out in any case during the first year. However, we find similar drops in enrollment rates 6, 9, and 12 months after finishing ninth grade (see Fig. 2). This suggests that the reform did actually affect some low-achieving boys, who would otherwise have continued into VET. When we broaden the scope and look at all the different types of education, we can see that this group of low-achieving boys did not enroll in other upper secondary 


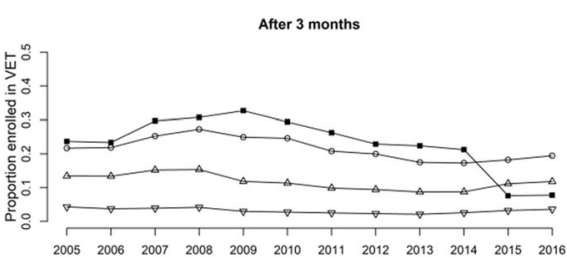

After 9 months

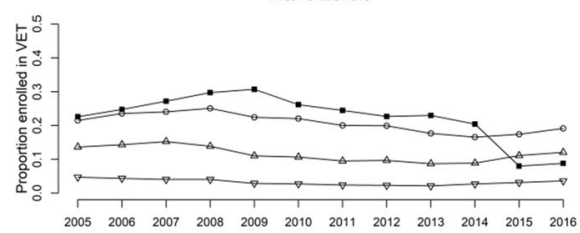

After 6 months

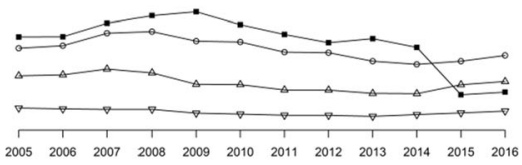

After 12 months

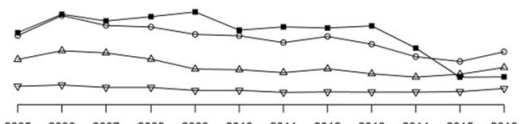

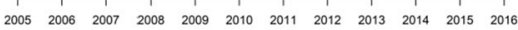

$\rightarrow$ GPA $<02 \quad-002<=$ GPA $<04 \triangle 04<=$ GPA $<07 \rightarrow-G P A>=07$

Fig. 2 Proportion of boys enrolled in VET by time since finishing ninth grade in Denmark and by GPA in ninth grade final exams in Danish and math

education programs in 2015: only 2\% enrolled in the academic track in 2015 (see Table 4 in the Appendix). In fact, most boys with GPAs below the admission requirement in 2015 continued into 10th grade $(73 \%)$. The descriptive statistics also suggest that the policy reform increased exits from the education system as the last $17 \%$ of the low-achieving boys in 2015 failed to enroll in any type of education after ninth grade. This is a $52 \%$ increase in the proportion of boys who left the education system from 2014 to 2015.

Figure 3 shows the proportion of boys with at least one criminal charge 3,6, 9, and 12 months after they finish ninth grade for the four GPA groups (as mentioned above in Fig. 2) in the years 2005-2015..$^{9}$ The crime rate levels are different for these four groups, as we would expect, but the overall time trends are the same for the groups in

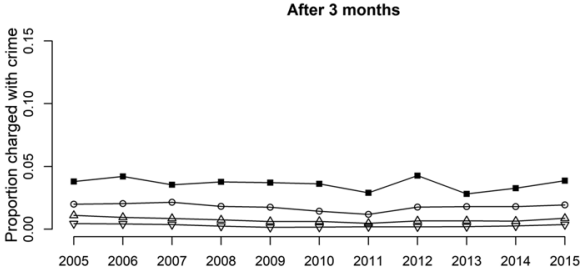

After 9 months

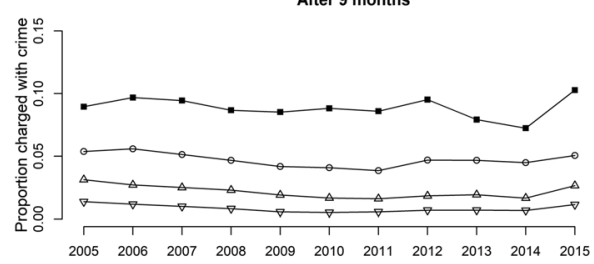

After 6 months

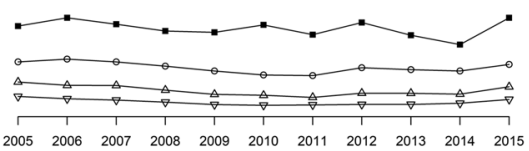

After 12 months

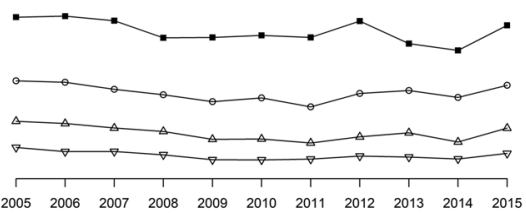

$\rightarrow \mathrm{GPA}<02 \rightarrow 02<=\mathrm{GPA}<04-04<=\mathrm{GPA}<07 \rightarrow-\mathrm{GPA}>=07$

Fig. 3 Proportion of boys charged with a criminal offence by time since finishing ninth grade in Denmark and by GPA in ninth grade final exams in Danish and math 
the years before the implementation of the admission requirement (even across all four follow-up periods). The downward trend in crime rates reflects the general decline in youth crime in the period (Andersen et al. 2016). This finding supports the parallel trends we saw in the enrollment rates for VET in Fig. 2 before the policy reform and gives descriptive support to the application of the DD design. Moreover, it is notable that from 2014 (pre-reform) to 2015 (post-reform), the crime rate increases for lowachieving boys, while the crime rates are rather stable for the other three GPA groups. Again, this pattern is observable across all follow-up periods, though more pronounced after 6, 9, and 12 months.

Table 1 presents VET program enrollment rates and the cumulative proportion of boys with a criminal charge 3, 6, 9, and 12 months after finishing ninth grade for boys who did not fulfill the admission requirement and boys who fulfilled the admission requirement in 2014 and 2015. Similarly to Fig. 2, for low-achieving boys, we see a significant and substantial drop in enrollment in VET from 2014 to 2015 for all months, but for boys who fulfill the admission requirement, Table 1 shows no substantial differences in enrollment rates in 2014 and $2015 .{ }^{10}$ In addition, the table reveals more clearly than Fig. 2 that for both GPA groups the enrollment rates drop from 9 to 12 months in both 2014 and 2015. This decrease happens when some boys have a summer break in-between the basic program and the main program of their VET, and therefore, they are not formally enrolled in education. For low-achieving boys, the proportion with criminal charges does not differ 3 months after finishing ninth grade. But we do observe an increase in the cumulative proportion that had been charged with a crime after 6 and 9 months. This difference, however, fades almost completely after 12 months (and is only statistically significant at the $10 \%$ level). For boys who fulfill the admission requirements, we also observe differences across the 2 years, but these differences are comparatively small.

At face value, the descriptive results point to a possible criminogenic effect of the reform for boys who do not fulfill the admission requirements - but only 6 and 9 months after they finish ninth grade. However, such a conclusion could be too hasty, as the policy reform may have diverted effects that challenge simple pre- and post-reform comparisons. The left side of Fig. 4 illustrates the (cumulative) proportion of boys who got a specific GPA in ninth grade final exams in the subjects Danish and math among all 15- to 18-year-old boys, who finished ninth grade in the respective years from 2010 to 2016. The figure shows a general trend towards higher grade point averages in Danish and math over the years 2010-2015. In particular, 2015 stands out with an increase in grades over the entire scale, which we do not observe for previous years or for subjects (English and Natural Sciences ${ }^{11}$ ) that the reform does not affect. We interpret the inflation of grades in Danish and math across the reform year to imply that some boys "migrated" from a lower to a higher grade group because of the reform, which may challenge the comparability of the pre- and post-reform groups with grades below 02.

\footnotetext{
${ }^{10}$ The table shows a significant increase in enrolment rates from 2014 to 2015 among boys who fulfil the admission requirement, but the sizes of the differences are small.

${ }^{11}$ Results are available upon request to the corresponding author.
} 
Table 1 The proportion of boys with VET enrollment or a criminal charge 3, 6, 9, and 12 months after finishing ninth grade in 2014 and in 2015 , divided by fulfillment of the admission requirement

\begin{tabular}{|c|c|c|c|c|c|c|}
\hline \multirow[t]{2}{*}{ Months } & \multicolumn{3}{|c|}{ Do not fulfill } & \multicolumn{3}{|c|}{ Do fulfill } \\
\hline & 2014 & 2015 & & 2014 & 2015 & \\
\hline \multicolumn{7}{|c|}{ VET enrollment } \\
\hline 3 & 21.3 & 7.6 & $* * *$ & 8.5 & 9.5 & $* * *$ \\
\hline 6 & 22.5 & 8.5 & $* * *$ & 8.6 & 9.6 & $* * *$ \\
\hline 9 & 20.4 & 8.0 & $* * *$ & 8.4 & 9.2 & $* * *$ \\
\hline 12 & 14.8 & 6.2 & $* * *$ & 6.0 & 5.8 & \\
\hline $\mathrm{N}$ & 2018 & 1343 & & 28,288 & 29,110 & \\
\hline \multicolumn{7}{|c|}{ Criminal charges } \\
\hline 3 & 3.3 & 3.9 & & 0.8 & 0.9 & \\
\hline 6 & 5.2 & 7.3 & $* *$ & 1.4 & 1.8 & $* * *$ \\
\hline 9 & 7.2 & 10.3 & $* * *$ & 2.0 & 2.5 & $* * *$ \\
\hline 12 & 9.6 & 11.6 & $*$ & 2.6 & 3.3 & $* * *$ \\
\hline $\mathrm{N}$ & 2018 & 1343 & & 28,288 & 29,110 & \\
\hline
\end{tabular}

Source: Administrative register data from Statistics Denmark.

$* p<0.10 ; * * p<0.05 ; * * * p<0.01$ for $t$ test of difference between 2014 and 2015

We use the wide range of information available from the administrative registers for the population of ninth grade students to explore whether the inflation of grades influences the compositions of students in the pre- and post-reform groups across the different GPA groups. Table 2 shows characteristics of the student body in four GPA groups before and after the introduction of the admission requirement. Across the four groups, we see a general change from 2014 to 2015 with an increase of students with lower socioeconomic backgrounds in groups with higher GPAs. These descriptive findings support our initial conclusion that the grade inflation from 2014 to 2015
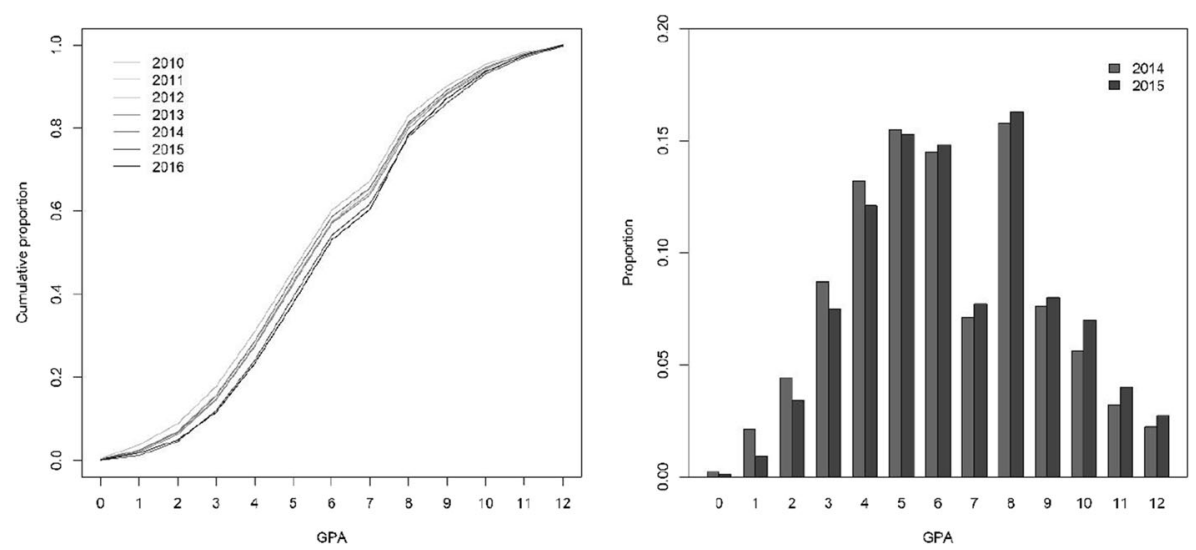

Fig. 4 GPAs in Danish and math final exams in ninth grade (only boys). Cumulative distribution in 20102016 (left figure) and histogram in 2014 and 2015 (right figure) 
affected the entire scale (i.e., all boys received slightly higher grades after the reform than they would have received before). As mentioned in the "Data and methods" sections, we therefore next apply a multi-group DD design in which we exploit the change in another part of the grade scale to take unobserved selection into account.

\section{Results from DD regression}

Table 3 presents the results from the multi-group DD regression models on enrollment in upper secondary vocational education and on the cumulative criminal charge rate 3 , 6, 9, and 12 months after finishing ninth grade. The DD models for enrollment show significant differences in enrollment rates in VET programs between boys finishing ninth grade with a GPA below 02 before and after the introduction of the admission requirement. Low-achieving boys who finish ninth grade in 2015 are 16 percentage points less likely to enter vocational education when compared with similar boys finishing ninth grade in 2014 (before the reform).

The DD models for criminal charges show an interesting pattern. First, although the point estimates increase in size with time after finishing ninth grade, we fail to detect a significant effect of the reform on cumulative charge rates the first 6 months after ninth grade. After 9 months, though, the difference reaches significance and is of a substantial magnitude. Boys who finished ninth grade in 2015 and did not fulfill the admission requirement to upper secondary education are 2.0 percentage points more likely to have been charged with a criminal offense 9 months after. If we compare the DD findings of the two outcomes and calculate the elasticity between enrollment rates and charge rates, our results suggest that a $1 \%$ decrease in enrollment rates to VET leads to a $0.69 \%$ increase in criminal charges among low-achieving boys after 9 months. ${ }^{12}$ However, when we look at the two groups 12 months after they finished ninth grade, the difference has disappeared, both in terms of estimate size ( 0.4 percentage points) and statistical significance. We thus find an increasing reform effect on criminally offending for boys with the lowest grade point averages throughout the middle of the school year, but not at the end of the school year. The inclusion of covariates in the regression models does not change this overall conclusion.

\section{Results from robustness analyses}

Figure 5 shows the results from 99 separate DD regression models for subsamples divided by the different percentiles in the grade point averages distribution, as was laid out in the "Data and methods" section. The DD estimates represent the difference between, for example, the lowest percentile and the remaining 99\% of the boys in 2014 and 2015 on the probability of enrolling in a vocational education/having a criminal charge 3, 6, 9, and 12 months after finishing ninth grade by percentiles of the lowest GPA in Danish or math final exams. The marks (in black) highlight point estimates from the DD regressions where more than $50 \%$ of the boys in that percentile had an absolute GPA below 02 (more than half of the post-reform observations behind the dark marks were thus affected by the reform). Overall, the results from this robustness

12 Elasticity $=\frac{\text { Percent change in charge rate because of reform }}{\text { Percent change in enrollment rate because of reform }}=\frac{\frac{0.103-0.072}{0.072}}{\frac{0.2040 .080}{0.204}}=0.689$. 


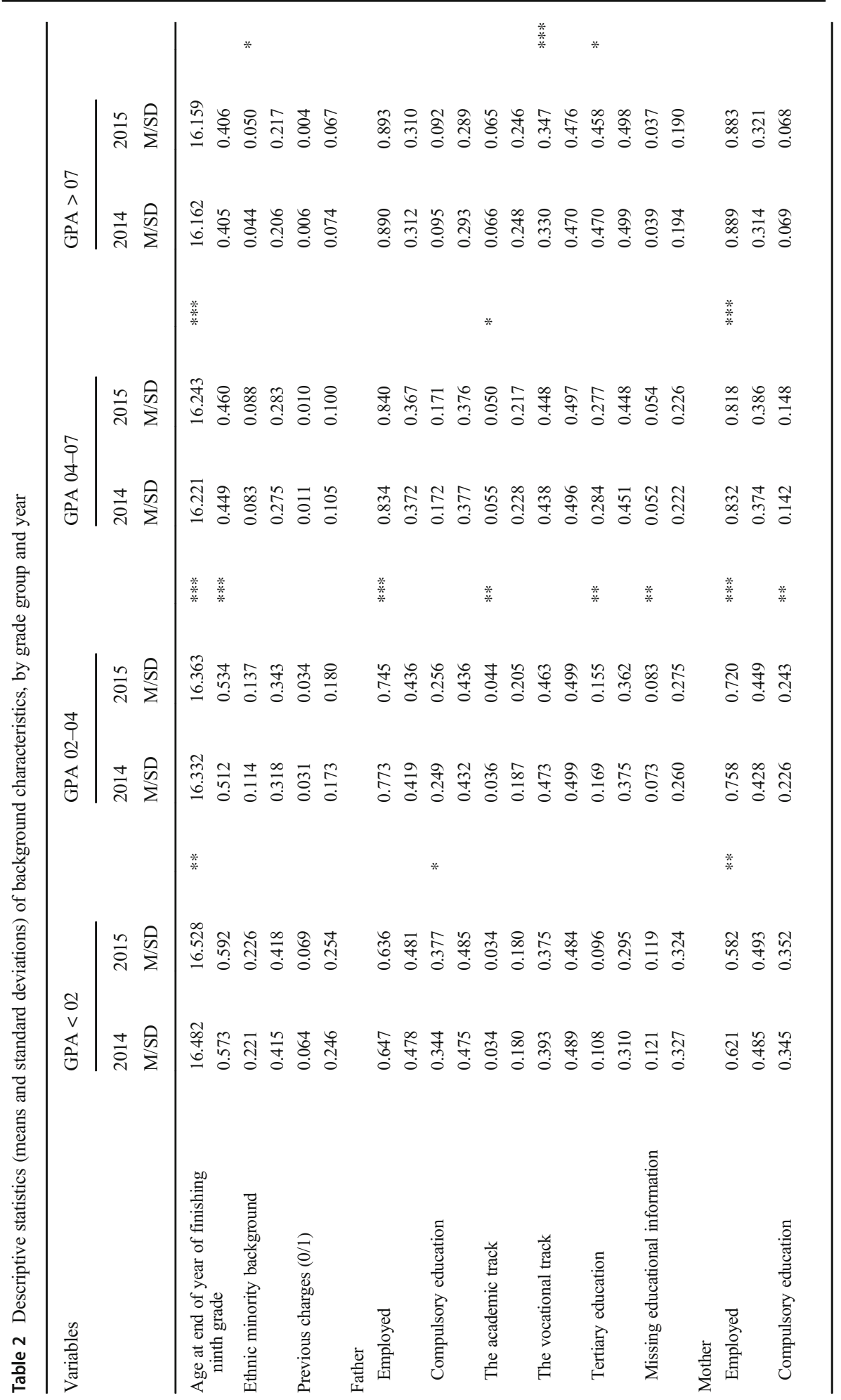




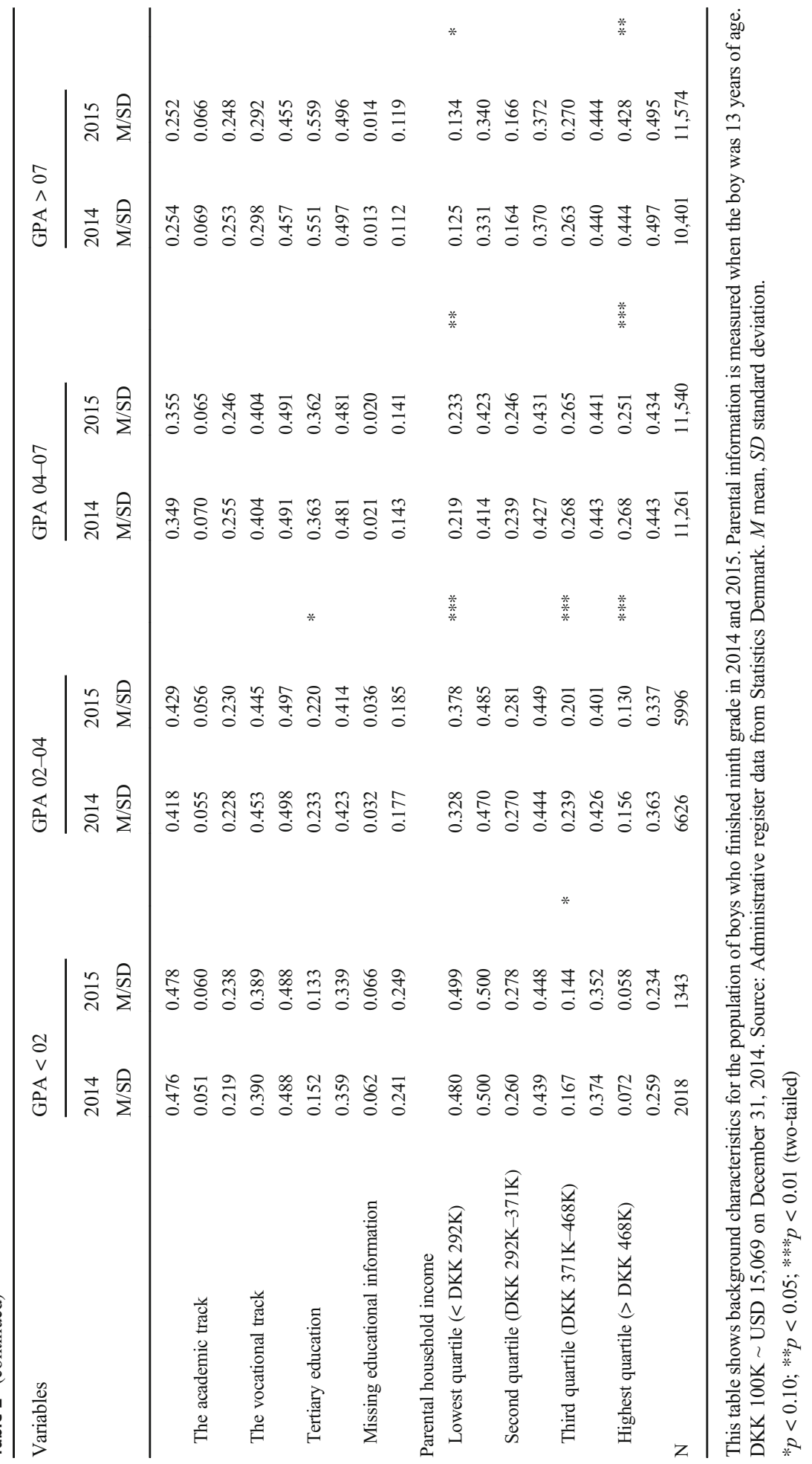


Table 3 Estimated reform effects on VET enrollment and criminal charges for boys who do not fulfill the admission requirement. Results from multi-group difference-in-differences models

\begin{tabular}{|c|c|c|c|c|c|}
\hline & & $\rho^{D D^{*}}$ & SE & Control variables & $\mathrm{N}$ \\
\hline \multirow[t]{8}{*}{ Enrollment in vocational education } & 3 months & $-0.163 * * *$ & $(0.014)$ & No & 60,759 \\
\hline & & $-0.164 * * *$ & $(0.014)$ & Yes & 60,759 \\
\hline & 6 months & $-0.171 * * *$ & $(0.015)$ & No & 60,759 \\
\hline & & $-0.171^{* * *}$ & $(0.015)$ & Yes & 60,759 \\
\hline & 9 months & $-0.151^{* * *}$ & $(0.014)$ & No & 60,759 \\
\hline & & $-0.151^{* * *}$ & $(0.014)$ & Yes & 60,759 \\
\hline & 12 months & $-0.079 * * *$ & $(0.012)$ & No & 60,759 \\
\hline & & $-0.079 * * *$ & $(0.012)$ & Yes & 60,759 \\
\hline \multirow[t]{8}{*}{ Charged with crime } & 3 months & 0.003 & $(0.007)$ & No & 60,759 \\
\hline & & 0.003 & $(0.007)$ & Yes & 60,759 \\
\hline & 6 months & 0.013 & $(0.009)$ & No & 60,759 \\
\hline & & 0.014 & $(0.009)$ & Yes & 60,759 \\
\hline & 9 months & $0.019 *$ & $(0.011)$ & No & 60,759 \\
\hline & & $0.020^{*}$ & $(0.011)$ & Yes & 60,759 \\
\hline & 12 months & 0.004 & $(0.012)$ & No & 60,759 \\
\hline & & 0.004 & $(0.011)$ & Yes & 60,759 \\
\hline
\end{tabular}

Source: Administrative register data from Statistics Denmark

$* p<0.10 ; * * p<0.05 ; * * *<0.01$ (two-tailed)

check support that the reform had an impact on VET enrollment rates and the rate of criminal charges among low-achieving boys in the first 9 months.

In the second robustness check, we reran our DD multi-group regression models on enrollment rates for years 2005-2016 and on crime rates for years 2005-2014 (Table 5, robustness check B). The results from these "pseudo-reform samples" support our main findings, as there are no differences in enrollment or crime rates for low-achieving boys in the majority of years with no reform. Although we do observe some statistically significant reform effects on VET enrollment in years when there was no reform, these estimates are either of opposite direction or they are numerically small compared with our main estimates. For criminal charges, the overall take-away from this robustness check is similar, as we observe the strongest response to the reform in the years that the reform took place. Again, while we do also find reform effects on charges in a few of the "pseudo-reform samples," these estimates are either of the opposite direction or substantially smaller than our main results. ${ }^{13}$

\footnotetext{
$\overline{13}$ There is one exception, namely, the pseudo-reform sample covering 2009/2010. Here, results point to decreasing VET enrollment and increasing charge rates. Estimates for VET enrollment are much smaller than in the true reform sample, whereas estimates for charges are somewhat similar to what we found for the true reform sample. This baffling result may, however, be due to the substantial general increase in criminal charges in Denmark from 2009 to 2010 (results available upon request to the corresponding author), and we therefore do not regard it as evidence against our main result (especially considering the low impact on VET enrollment rates).
} 
The results from our last robustness check also support our main conclusions. Here, we investigate whether our main results from the multi-group DD regression models depend on the specific (and somewhat arbitrary) choice of threshold for the comparison group, as explained in the "Data and methods" section. As the results are similar across the different thresholds, there are no signs that the findings are dependent on model specifications (Table 6 , robustness check $\mathrm{C}$ ).

\section{Discussion}

Research on the relationship between education and crime has typically focused on the consequences of dropping out of education for the risk of criminal involvement. More recent studies exploit natural experiments to examine the effects of the length of education, school starting age, and school attendance on criminal behavior. With this paper, we directed attention to a largely overlooked margin of the educational system, namely, enrollment in upper secondary education. Specifically, we focused on enrollment in vocational education and training (VET), which traditionally has been the predominant choice of upper secondary education for boys with low academic achievement in Denmark. We claim that the strong association between low academic achievement and the risk of coming into contact with the criminal justice system (e.g., Maguin and Loeber 1996) makes the enrollment margin of upper secondary education in general - and VET in particular - relevant for understanding the relationship between education and crime.

Results from our empirical analyses, which exploit an educational policy reform for identification, partly support the claim by identifying an effect preventing lowachieving boys from enrolling in upper secondary education after finishing ninth grade and a short-term increase in criminal charges. More specifically, we estimate that the reform decreased the enrollment rates for VET among low-achieving boys by 16 percentage points 3 months after finishing ninth grade, a substantial decline that was not reflected by any increased uptake in other tracks of upper secondary education. Focusing on potential criminogenic effects of the reform, our empirical results suggest that the reform led to a 2 percentage points higher cumulative rate of criminal charges 9 months after finishing ninth grade (from a baseline of $7.2 \%$ in the pre-reform group, corresponding to a $28 \%$ relative increase in criminal charges). However, we find no reform effect on cumulative offending rates after 12 months. Therefore, our results suggest that educational enrollment itself may decrease criminal behavior among low-achieving boys in the very short run (in the middle of the school year) but not in the slightly longer run (towards the end of the school year). In conjunction with a series of robustness checks, which support our main results, we argue that there is a short-term impact of the 2015 reform on criminal charges - although statistically small.

The policy reform affected VET enrollment to a far greater degree than it affected criminal charges. At first glance, this finding implies a low elasticity between VET enrollment and criminal charges, something that does not seem to echo findings from research on the crime consequences of dropping out of education, which generally finds larger effects. One exception is Sweeten et al. (2009), who find no long-term effects of dropping out on either the prevalence or variety of boys' delinquency, and only small 

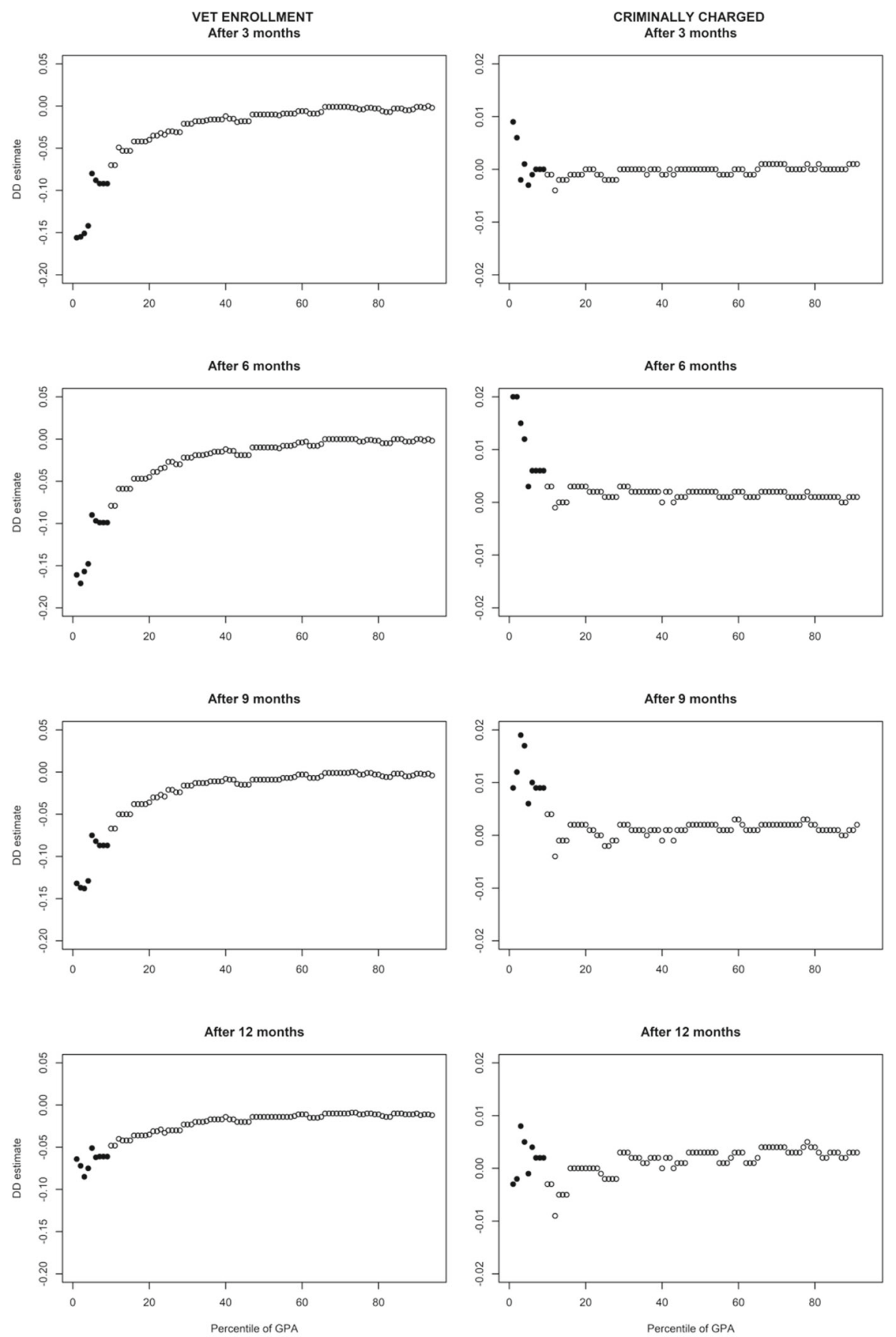

- More than $50 \%$ have below $02 \circ$ Less than $50 \%$ have below 02

Percentiles over 94 (VET enrollment)/91 (criminal charges) are not presented in the graph because of too few observations. 
Fig. 5 Results from robustness check A: Point estimates from separate DD models by GPA percentiles for enrollment in vocational education and criminal charges 3, 6, 9, and 12 months after finishing ninth grade

short-term crime effects of dropping out for economic or unclassifiable reasons. ${ }^{14}$ Yet here, three important points of attention should be noted. First, our empirical setup and data availability allow us to measure criminal charges for offenses committed during a short follow-up period only, up to 12 months after the boys finished ninth grade. Asslund et al. (2018) find that the effects on crime of an extension of the length of VET programs mainly appear at the third year after enrollment, which could suggest that later reform effects on crime could also occur in our context. Hence, the small shortterm effect of the reform on criminal charges in the first 9 months could cumulate into a substantial size over a longer haul. Bell et al. (2018), for example, find that keeping youths in school not only prevents criminal offending during school years, it also has a preventive effect in the long run after leaving school - a dynamic incapacitation effect, as they call it. This, of course, is merely a hypothesis in need of further empirical testing, as, for example, Huttunen et al. (2019) find effects of secondary education on crime only 5 years after admission, but no effect after 6 years in Finland.

One additional limitation of this study, caused by the short follow-up period, is that we can only analyze reform effects for the population of boys. The rate of criminal charges among girls in Denmark is too low for us to estimate separate statistical models of the crime effects for girls. As previous studies find different effects of education on criminal behavior for girls, it will be important for future studies to investigate the crime effects of educational enrollment for girls.

The second point of attention is that, although effects are statistically small, looking at short-term effects is important for understanding how the link between education and crime unfolds. When we find policy effects on criminal charges after 9 months, but not after 12 months, this can indicate that incapacitation may be at play in the short-term. After 9 months, those enrolled in VET are still in school; after 12 months, some boys are on summer break in-between the basic program and the main program of their VET, where incapacitation is arguably lower. Moreover, it is important to recall that the 2 percentage point increase in criminal charges after 9 months is driven not by all lowachieving boys in our sample but only by those who would have enrolled in VET were it not for the reform (the compliers). Among the low-achieving boys, $73 \%$ continued into the optional 10th grade in compulsory school. These descriptive results may help us explain the small effects we find compared with other similar research results. Because the majority of low-achieving boys continued into 10th grade, they were still in school, despite being pushed out of upper secondary education, and they were thereby incapacitated. This incapacitation in 10th grade may have diminished the effect size of the policy reform on criminal behavior.

Incapacitation is not the only possible interpretation of our findings, however. In support of strain theory, the reform prevented some boys who expected to enroll in

\footnotetext{
${ }^{14}$ Sweeten et al. (2009) find that while dropping out for unclassified reasons leads to an increase in the prevalence of delinquency and crime variety, dropping out for financial reasons leads to a decrease in the prevalence of delinquency and crime variety.
} 
VET from achieving their goal. Furthermore, the abrupt nature of the reform could potentially push some of the marginal boys into criminal behavior because they felt that odds were turned against them by the reform. In both cases, we would expect effects on crime to occur as an immediate response to the "new" circumstances. In support of social bonds theories, we find that the reform increased low-achieving boys' idleness by $52 \%$, and the potential loss of social bonds caused by leaving the education system can contribute to explain the short-term crime effects. As such, our results support different theoretical lines of work and our results cannot unambiguously reject any of the theories (indeed, all three mechanisms could potentially be at play at the same time).

The third point of attention concerns the issue that low-achieving boys who did not enroll in VET because of the admission requirements might eventually have dropped out of education even in the absence of the reform, implying that the consequences of no educational enrollment for criminal behavior could simply be a matter of timing. The disappearance of a significant effect from 9 months to 12 months could thus indicate that a push out of the education system causes some boys to commit crime earlier than they would otherwise have (results from our descriptive analyses of enrollment rates after 6,9, and 12 months do not indicate that this is the case, however). On the one hand, this interpretation of boys dropping out can support routine activity theory, as education then does not incapacitate the boys (as was just discussed). Considering the association between age at criminal onset and a person's criminal trajectory (e.g., Liberman et al. 2014), such a finding would seem to make it even more important to focus on educational enrollment to inhibit or incapacitate criminal careers. On the other hand, dropping out of VET could also lead to the loss of social bonds. In such a case, the reform can contribute to the loss of social bonds to occur earlier than in the absence of the reform, and entailing earlier criminal behavior.

With the empirical setup presented in this paper, we also direct attention to the nature of natural experiments, which should be of interest to policy evaluators more broadly. Ideally, the 2015 reform simply and exogenously changed boy's enrollment in VET, and we could compare enrollment and crime rates among low-achieving boys who finished ninth grade before and after the reform. Yet, our descriptive legwork revealed a feature that often accompanies natural experiments, namely, that legal reforms can offset responses along several margins that were either intended or unintended (Dunning 2012). In terms of natural experiments' potential for providing valid research designs capable of identifying causal effects, our study represents a textbook example of a natural experiment that is not flawless. One key consequence of introducing grade-specific requirements for VET enrollment was, as we have shown, substantial grade inflation. Such grade inflation could reflect ninth-grade teachers helping marginal students to live up to the requirements, or it could reflect marginal students making an extra effort to squeeze themselves above the grade threshold; either way, such a response challenges the natural experiment's suitability for causal inference. We approach this challenge by exploiting the level of detail of register data from Denmark to tailor a multi-group difference-in-differences empirical model, which explicitly aims to take the grade inflation (and the unobserved correlates hereof) into account in the estimations. Even though our empirical model rests on untestable assumptions, we still believe this exercise should invite other researchers to consider carefully the full range of responses to the natural experiments that they analyze instead of merely assuming "perfect" natural experiments. 
Concentrating on outcomes, although small, the short-term effect on criminal charges that we have identified in this paper were most likely not intended by the policy-makers behind the reform; as mentioned, they aimed to increase the quality of VET programs. This shows that reforms may produce undesired outcomes-especially when the flipside of policy reforms affects the life chances of vulnerable groups.

\section{Appendix}

Table 4 Educational enrollment in August-September for boys who do not fulfill the admission requirements in 2014 and 2015 and all boys who finish ninth grade in 2014 and 2015

\begin{tabular}{|c|c|c|c|c|c|c|c|c|c|c|}
\hline \multirow[t]{2}{*}{ Educational enrollment } & \multicolumn{5}{|c|}{ GPA below 02} & \multicolumn{5}{|c|}{ All boys } \\
\hline & 2014 & 2015 & Diff & $\operatorname{Diff}(\%)$ & & 2014 & 2015 & Diff & $\operatorname{Diff}(\%)$ & \\
\hline Continue in 10 th grade & 65.1 & 72.8 & 7.8 & 12 & $* * *$ & 49.0 & 49.3 & 0.2 & 0 & \\
\hline The academic track & 1.2 & 1.8 & 0.6 & 50 & & 33.7 & 35.0 & 1.4 & 4 & $* * *$ \\
\hline $\begin{array}{l}\text { Vocational upper } \\
\text { secondary education }\end{array}$ & 20.4 & 7.6 & -12.8 & -63 & $* * *$ & 11.1 & 10.6 & -0.5 & -4 & $* *$ \\
\hline Other education & 2.4 & 1.2 & -1.2 & -51 & $* *$ & 0.7 & 0.3 & -0.5 & -64 & $* * *$ \\
\hline $\begin{array}{l}\text { No enrollment in } \\
\text { upper secondary } \\
\text { education }\end{array}$ & 10.9 & 16.6 & 5.7 & 52 & $* * *$ & 5.5 & 4.8 & -0.6 & -11 & $* * *$ \\
\hline $\mathrm{N}$ & 2018 & 1343 & & & & 30,306 & 30,453 & & & \\
\hline
\end{tabular}

Source: Administrative register data from Statistics Denmark

$* p<0.10 ; * * p<0.05 ; * * * p<0.01$ 


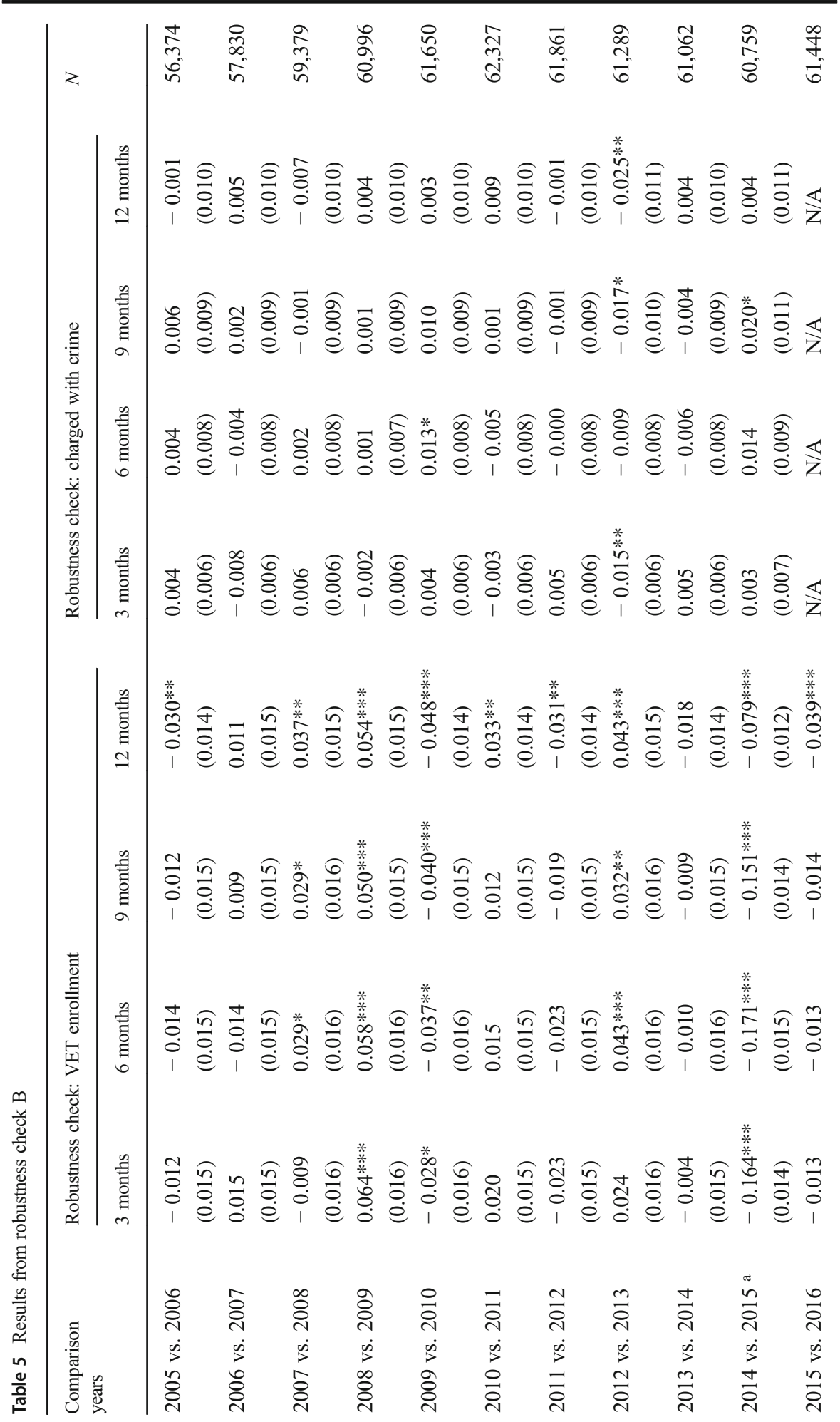




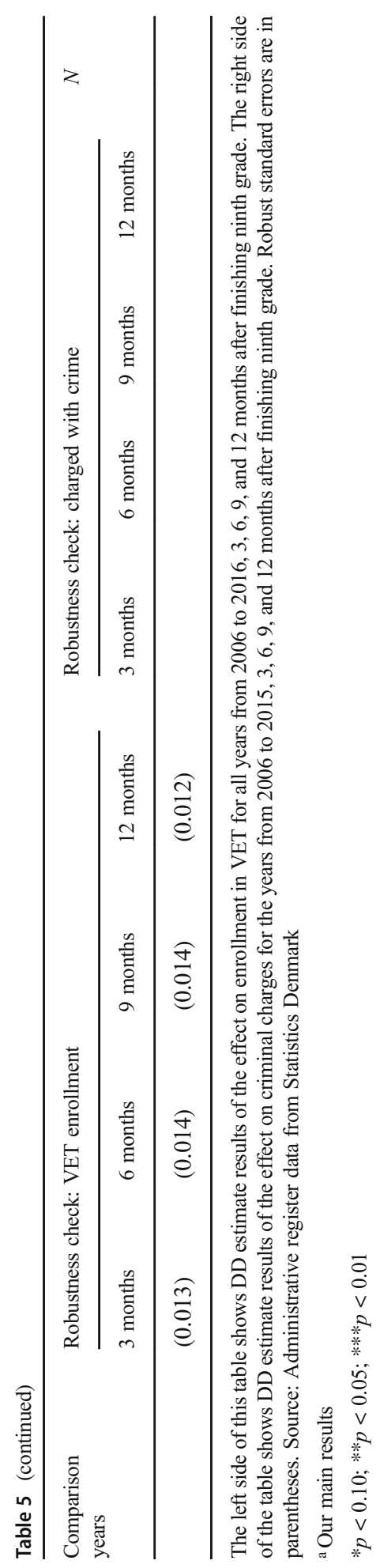




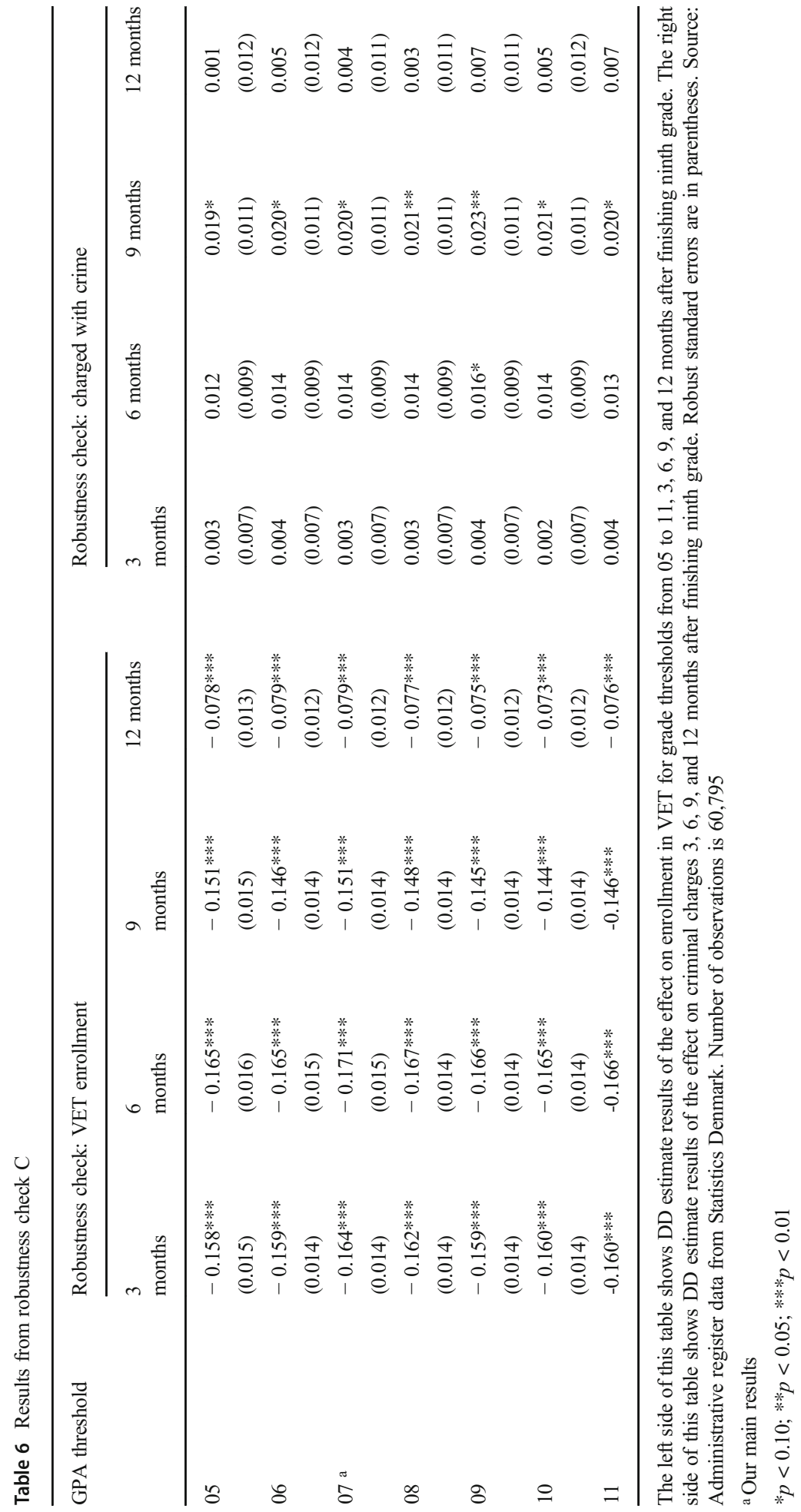


Open Access This article is licensed under a Creative Commons Attribution 4.0 International License, which permits use, sharing, adaptation, distribution and reproduction in any medium or format, as long as you give appropriate credit to the original author(s) and the source, provide a link to the Creative Commons licence, and indicate if changes were made. The images or other third party material in this article are included in the article's Creative Commons licence, unless indicated otherwise in a credit line to the material. If material is not included in the article's Creative Commons licence and your intended use is not permitted by statutory regulation or exceeds the permitted use, you will need to obtain permission directly from the copyright holder. To view a copy of this licence, visit http://creativecommons.org/licenses/by/4.0/.

\section{References}

Agnew, R. (1992). Foundation for a general strain theory of crime and delinquency. Criminology, 30(1), 47-88.

Agnew, R., Brezina, T., Wright, J. P., \& Cullen, F. T. (2002). Strain, personality traits, and delinquency: Extending general strain theory. Criminology, 40(1), 43-72.

Andersen, L. H. (2018). Danish Register Data: flexible administrative data and their relevance for studies of intergenerational transmission. In V. I. Eichelsheim \& S. G. A. van de Weijer (Eds.), Intergenerational continuity of criminal and antisocial behaviour: An international overview of studies. Cambridge UK: Routledge.

Andersen, L. H., Anker, A. S. T., \& Andersen, S. H. (2016). A formal decomposition of declining youth crime in Denmark. Demographic Research, 35, 1303-1316.

Angrist, J. D., \& Pischke, J. S. (2008). Mostly harmless econometrics: an empiricist's companion. Princeton: Princeton University Press.

Åslund, O., Grönqvist, H., Hall, C., \& Vlachos, J. (2018). Education and criminal behavior: Insights from an expansion of upper secondary school. Labour Economics, 52, 178-192.

Bachman, J., O'Malley, P., \& Jerome, J. (1978). Youth in transition, volume VI: adolescence to adulthoodchange and stability in the lives of young men. Ann Arbor: University of Michigan Press.

Bäckman, O. (2017). High school dropout, resource attainment, and criminal convictions. Journal of Research in Crime and Delinquency, 54(5), 715-749.

Beatton, T., Kidd, M. P., Machin, S., \& Sarkar, D. (2018). Larrikin youth: crime and Queensland's earning or learning reform. Labour Economics, 52, 149-159.

Bell, B., Costa, R., \& Machin, S. (2016). Crime, compulsory schooling laws and education. Economics of Education Review, 54, 214-226.

Bell, B., Costa, R., \& Machin, S. J. (2018). Why does education reduce crime? Discussion Paper Series. IZA Institute of Labor Economics.

Bennett, P. (2018). The heterogeneous effects of education on crime: evidence from Danish administrative twin data. Labour Economics, 52, 160-177.

Bjerk, D. (2012). Re-examining the impact of dropping out on criminal and labor outcomes in early adulthood. Economics of Education Review, 31(1), 110-122.

Brugård, K. H., \& Falch, T. (2013). Post-compulsory education and imprisonment. Labour Economics, 23, 97-106.

Card, D. (1999). The causal effect of education on earnings. In Handbook of labor economics (Vol. 3, pp. 18011863). Elsevier.

Cohen, L. E., \& Felson, M. (1979). Social change and crime rate trends: a routine activity approach. American Sociological Review, 588-608.

DEA (2016). Hvad betyder grundskolekarakter for vejen gennem uddannelsessystemet?. The Think Tank DEA, Notat 53, Copenhagen.

Dunning, T. (2012). Natural experiments in the social sciences: a design-based approach. Cambridge University Press.

Elliott, D. S., \& Voss, H. L. (1974). Delinquency and dropout. Lexington: Lexington Books.

Farrington, D., Gallagher, B., Morley, L., Ledger, R. S., \& West, D. (1986). Unemployment, school leaving and crime. British Journal of Criminology, 26(4), 335-356.

Hirschi, T. (1969). Causes of delinquency. Berkeley: University of California Press.

Hjalmarsson, R., Holmlund, H., \& Lindquist, M. J. (2015). The effect of education on criminal convictions and incarceration: causal evidence from micro-data. The Economic Journal, 125(587), 1290-1326.

Huttunen, K., Pekkarinen, T., Uusitalo, R., \& Virtanen, H. (2019). Lost boys: access to secondary education and crime. (Working paper). Discussion Paper Series. IZA Institute of Labor Economics.

Jacob, B. A., \& Lefgren, L. (2003). Are idle hands the devil's workshop? Incapacitation, concentration, and juvenile crime. The American Economic Review, 93(5), 1560-1577. 
Jarjoura, G. R. (1993). Does dropping out of school enhance delinquent involvement? Results from a largescale national probability sample. Criminology, 31(2), 149-172.

Kirk, D. S., \& Sampson, R. J. (2013). Juvenile arrest and collateral educational damage in the transition to adulthood. Sociology of Education, 86(1), 36-62.

Landersø, R., Nielsen, H. S., \& Simonsen, M. (2017). School starting age and the crime-age profile. The Economic Journal, 127(602), 1096-1118.

Laub, J. H., \& Sampson, R. J. (1993). Turning points in the life course: why change matters to the study of crime. Criminology, 31(3), 301-325.

Liberman, A. M., Kirk, D. S., \& Kim, K. (2014). Labeling effects of first juvenile arrests: secondary deviance and secondary sanctioning. Criminology, 52(3), 345-370.

Lochner, L., \& Moretti, E. (2004). The effect of education on crime: evidence from prison inmates, arrests, and self-reports. American Economic Review, 94(1), 155-189.

Luallen, J. (2006). School's out... forever: a study of juvenile crime, at-risk youths and teacher strikes. Journal of Urban Economics, 59(1), 75-103.

Machin, S., Marie, O., \& Vujić, S. (2011). The crime reducing effect of education. The Economic Journal, 121(552), 463-484.

Machin, S., Marie, O., \& Vujić, S. (2012). Youth crime and education expansion. German Economic Review, 13(4), 366-384.

Maguin, E., \& Loeber, R. (1996). Academic performance and delinquency. Crime and Justice Chicago (Vol. 20, pp. 45-264). The University of Chicago Press.

Moffitt, T. E. (1993). Adolescence-limited and life-course-persistent antisocial behavior: a developmental taxonomy. Psychological Review, 100(4), 674.

Oreopoulos, P., \& Salvanes, K. G. (2011). Priceless: the nonpecuniary benefits of schooling. Journal of Economic Perspectives, 25(1), 159-184.

Piquero, A. R., Farrington, D. P., \& Blumstein, A. (2003). The criminal career paradigm. Crime and Justice, 30, 359-506.

Sweeten, G., Bushway, S. D., \& Paternoster, R. (2009). Does dropping out of school mean dropping into delinquency? Criminology, 47, 47-91.

The Danish Economic Council of the Labour Movement (2013). Mange unge har ikke afsluttet folkeskolen. København: Arbejderbevægelsens Erhvervsråd.

The Danish Evaluation Institute. (2018). Søgning, udbud og elevgrundlag på ungdomsuddannelserne - En kortlægning af udviklingen fra 2009 til 2017.

The Danish Government, Venstre, The Danish People's Party, The Socialist People's Party, The Conservative People's Party og Liberal Alliance (2014). Aftale om Bedre og mere attraktive erhvervsuddannelser.

The Danish Ministry of Children and Education (2015). Optag og optagelsesproces på erhvervsuddannelserne 2015. The Danish Ministry of Children and Education.

The Danish Ministry of Children and Education (2018). Frafald og fuldførelse på erhvervsuddannelserne.

Thornberry, T. P., Moore, M., \& Christenson, R. L. (1985). The effect of dropping out of high school on subsequent criminal behavior. Criminology, 23(1), 3-18.

Publisher's note Springer Nature remains neutral with regard to jurisdictional claims in published maps and institutional affiliations.

Kira Solveig Larsen is a $\mathrm{PhD}$ Fellow at The Danish Center for Social Science Research in Copenhagen, Denmark, and the Department of Sociology at the University of Copenhagen. Her research focuses on crime prevention and transitions in the education system.

Lars Højsgaard Andersen is senior researcher at the Rockwool Foundation Research Unit in Copenhagen, Denmark. Research interests cover, among other areas, quantitative criminology, family dynamics, and social stratification.

Britt Østergaard Larsen is researcher at The Danish Center for Social Science Research in Copenhagen, Denmark. Research interests include crime prevention, including the importance of education and various types of criminal sanctions. 